\title{
POHLIA LUTESCENS (MIELICHHOFERIACEAE, BRYOPHYTA) IN RUSSIA POHLIA LUTESCENS (MIELICHHOFERIACEAE, BRYOPHYTA) В РОССИИ
}

\author{
ANDREY G. BEZGODOV ${ }^{1} \&$ ELENA A. IGNATOVA ${ }^{2}$ \\ АНДРЕЙ Г. БЕЗГОДОВ ${ }^{1}$, ЕЛЕНА А. ИГНАТОВА ${ }^{2}$
}

Abstract

Pohlia lutescens, a species with rhizoidal tubers, is found in Russia for the first time. It was simultaneously revealed in several points in Perm Province (Northern Ural Mountains), and in single localities in Amurskaya Province and Khabarovsk Territory. Description and illustrations based on specimens from Russia are provided, ecology and distribution of the species are discussed.

Резюме

Pohlia lutescens, вид с ризоидными клубеньками, впервые найден в России. Он был одновременно выявлен в нескольких местонахождениях в Пермской области, а также в единичных точках в Амурской области и в Хабаровском крае. Приводятся описание и иллюстрации вида по образцам из России, обсуждается его экология и распространение.

KEYWORDS: mosses, Pohlia, rhizoidal tubers, new record, Russia.

A small-sized, non-fruiting Pohlia plants, growing in small quantity, are usually a special subject of attraction for bryologists during collecting in the field. Among others, two such specimens were gathered by a senior author (AB) in Norsky Nature Reserve (Amurskaya Province, Russian Far East), on steep slopes to the river bank. Both were found to have rhizoidal tubers. One of them was identified as P. lescuriana (Sull.) Ochi, as having rounded, smooth, yellowish-orange tubers ca. $100 \mu \mathrm{m}$ in diameter. However, in another specimen, tubers were smaller, ca. $50 \mu \mathrm{m}$, pale yellow and with knobby surface. This character, together with pale green color of plants, suggested its identification as $P$. lutescens (Limpr.) H. Lindb., a species not previously reported from Russia. In addition, after a revision of some enigmatic Pohlia specimens from Perm Province (North Urals), P. lutescens was also detected. At the same time, other author (EI) also collected one specimen of the species in the Russian Far East (Khabarovsk Territory, Botchinsky Nature Reserve). It raises a suspicion of its wider distribution in Russia, because it can be easily overlooked and misidentified due to a small size and scanty of tubers. Therefore we provide a description and illustrations of the species based on specimens from Russia and information on its habitats in known localities.

Pohlia lutescens (Limpr.) H. Lindb., Acta Soc. Fauna Fl. Fenn. 16(5): 11. 1899. — Webera lutescens Limpr., Laubm. Deutschl. 2: 270. 272. $1892 . \quad$ Figs.1-2.

Plants small, pale green or yellowish-green, not or slightly glossy, in loose tufts or patches or growing as individual plants among other bryophytes. Stems sim- ple, 4-5[-10] $\mathrm{mm}$, green or occasionally reddish in lower part, shoots loosely foliate. Leaves slightly flexuose when dry, erect-spreading when moist, narrow lanceolate, $0.7-$ $0.9 \times 0.2-0.25 \mathrm{~mm}$, gradually tapering to a slender acumen, acuminate; costa narrow, ending far below apex or subpercurrent; margins plane or weakly recurved in middle part, sharply denticulate in upper half of leaf; lamina unistratose, cells linear, upper laminal cells $55-100 \times 8$ $11 \mu \mathrm{m}$, median laminal cells $70-150[-180] \times 8-10 \mu \mathrm{m}, 55-$ $140 \times 10-12 \mu \mathrm{m}$. Dioicous, sporophytes rare, found only once in Perm Province. Perichaetial leaves much longer than stem leaves, linear-lanceolate, $2.5[-3.0] \times 0.3 \mathrm{~mm}$, costa percurrent to excurrent; margins plane or \pm recurved. Seta 7-8 mm; capsule horizontal or slightly inclined, pyriform, 1.7-1.8 $\times 0.8-0.9 \mathrm{~mm}$; stomata superficial; exostome teeth yellow; spores 18-22 $\mu \mathrm{m}$. Rhizoids reddish, finely papillose, thinner rhizoids pale, bearing pale yellow or occasionally light reddish-brown, rounded to ovoid, knobby gemmae $40-55 \times 30-55 \mu \mathrm{m}$.

Differentiation. Pohlia lutescens differs from another tuber-bearing species, $P$. lescuriana, in smaller size of rhizoidal tubers, $40-55 \mu \mathrm{m}$ vs. $70-120 \mu \mathrm{m}$, as well as their outline, knobby vs. smooth, and also color, usually pale yellow vs. orange or pale brownish. The latter character however has been found more variable, as gemmae from an exposed place in Amurskaya Province sometimes are light reddish-brown (Figs. 2, 4-6). Pohlia lutescens has slightly narrower laminal cells, $8-10 \mu \mathrm{m}$ vs. (8-)10$12 \mu \mathrm{m}$ in P. lescuriana, and more sharply differentiated perichaetial leaves, linear-lanceolate vs. narrowly lanceolate.

1 - Tobolsk Complex Scientific Station, Ural branch of RAS, Academician Yuri Osipov Str., 15, Tobolsk, 626152 Russia - Poccия 626152, Тобольск, ул. Академика Юрия Осипова, 15, Тобольская комплексная научная станция Уральского отделения РАН; e-mail: bezgodovs@list.ru

2 - Moscow State University, Biological Faculty, Geobotany Dept., Moscow 119234 Russia - Россия 119234, Москва, Московский университет, Биологический факультет, каф. геоботаники; е-mail: arctoa@list.ru 


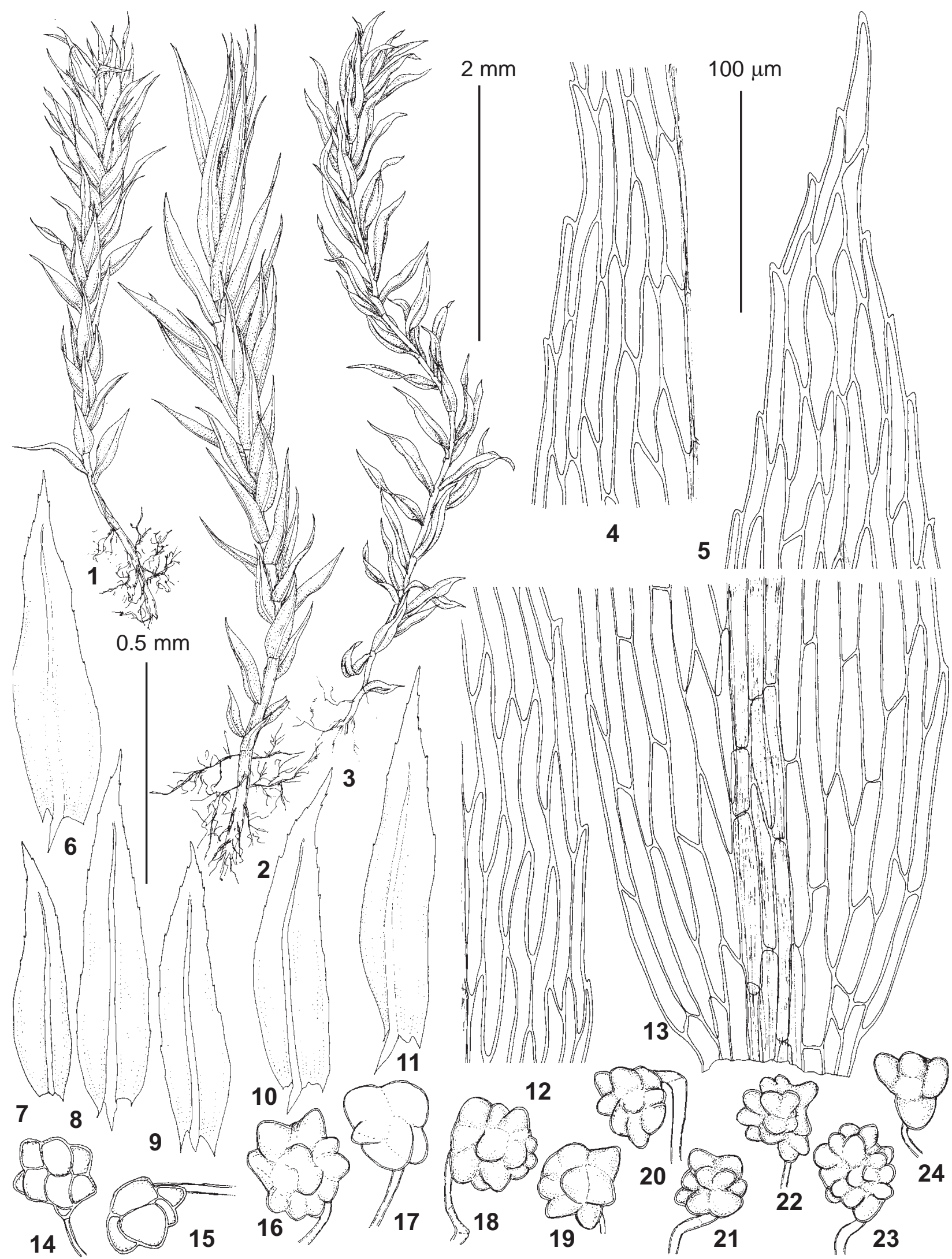

Fig. 1. Pohlia lutescens (Limpr.) H. Lindb. (1-2, 10-12, 14-18 - Amurskaya Province, Norsky Nature Reserve, 11.VII.2010, Bezgodov \#396a, MHA; 3-6, 8-9, 13, 21-24 - Perm Province, Vishersky Nature Reserve, 25.VI.2009, Bezgodov \#21, MHA; 7, 1920 - from Khabarovsk Territory, Botchinsky Nature Reserve, Ignatov \& Ignatova \#13-1079, MHA): 1, 3 - habit, dry; 2 - habit, wet; 4, 13 - median laminal cells; 5 - upper laminal cells; 6-11 - leaves; 13 - basal laminal cells; 14-24 - rhizoidal tubers. Scale bars: $2 \mathrm{~mm}$ for $1-3 ; 0.5 \mathrm{~mm}$ for $6-11 ; 100 \mu \mathrm{m}$ for $4-5,12-24$. 

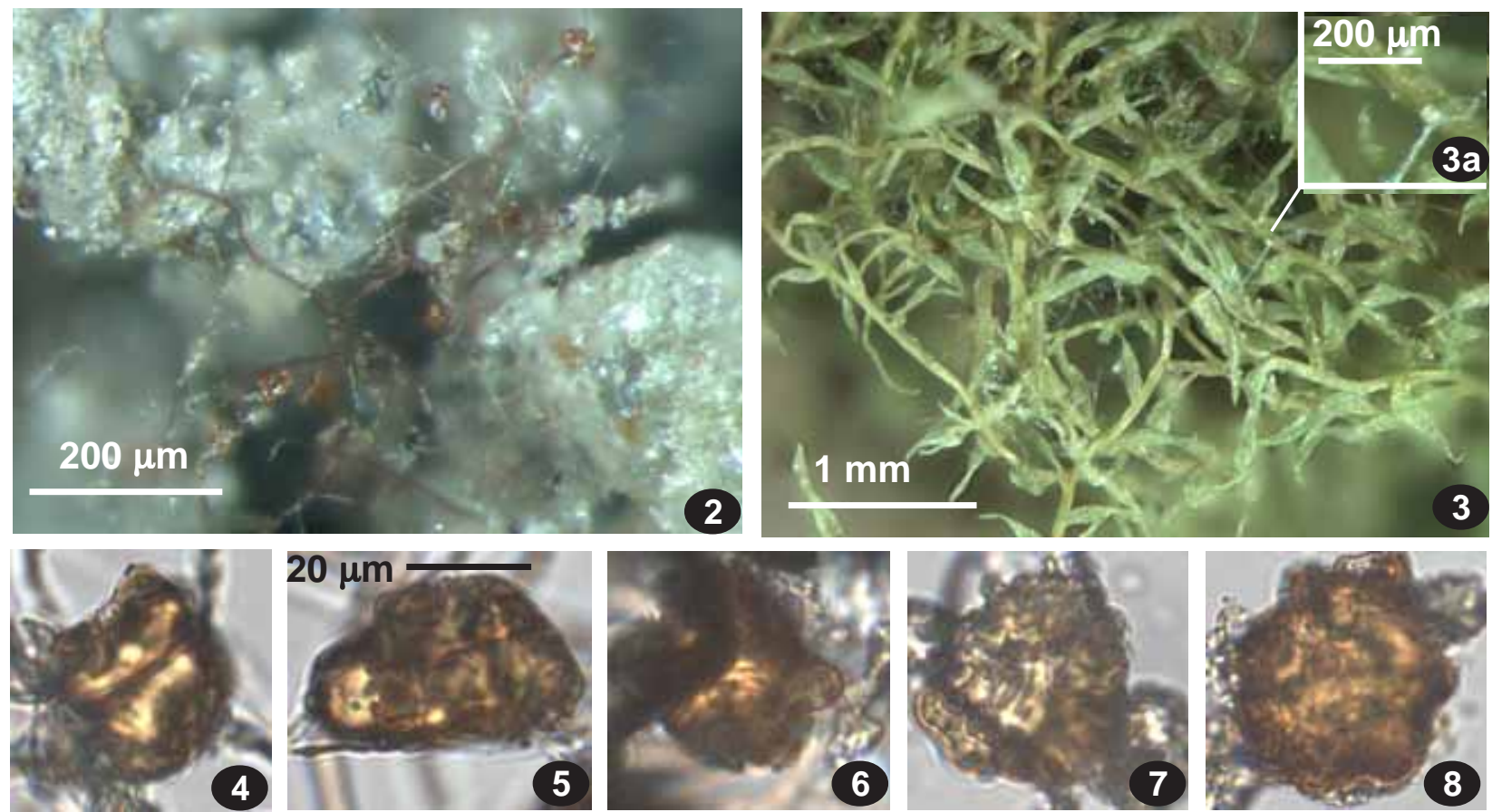

Figs. 2-8. Pohlia lutescens (Limpr.) H. Lindb. (2, 4-5 - from: Amurskaya Province, Norsky Nature Reserve, 11.VII.2010, Bezgodov \#396a, MHA; 3, 7-8 - from: Perm Province, Vishersky Nature Reserve, 25.VI.2009, Bezgodov \#21, MHA): 2 - rhizoids with tubers; 3 - habit of plants; 4-8 - rhizoidal tubers. Scale bars: $1 \mathrm{~mm}$ for 3; $200 \mu \mathrm{m}$ for 2, 3a; $20 \mu \mathrm{m}$ for 4-8.

It can be difficult to identify $P$. lutescens due to a small size of tubers and their pale color which makes them hardly visible under stereomicroscope; furthermore, they are often rather scanty. However, small size of plants, their pale color, small leaves with sharply denticulate upper margins and long and narrow laminal cells are suggesting characters of the species, and after a thorough search of tubers on rhizoids under a compound microscope at least few ones are usually found.

Specimens examined: EUROPEAN RUSSIA: Perm Province, Krasnovishersk District: Severnyj Kolchim River basin, Svetlyj Brook (60¹6'N - 57³9'E), 14.VIII.1996, Bezgodov \#2 (MHA); Vishersky State Nature Reserve: Vishersky Kamen' Mt. Range $\left(61^{\circ} 30^{\prime} \mathrm{N}-59^{\circ} 15^{\prime} \mathrm{E}\right), 25$.VI.2009, Bezgodov \#\#14, 21 (MHA); Khalsoriya River Valley (6130'30'”N - 59¹4'E), 18.VII.2009, Bezgodov \#575 (MHA, PPU); Munin-Tump Mt.

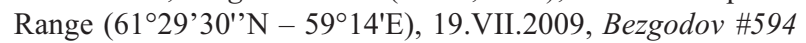
(MHA, PPU), S+. ASIAN RUSSIA: Amurskaya Province, Nora Nature Reserve, Norsky River, island near Meun River mouth (52 $\left.{ }^{\circ} 57^{\prime} \mathrm{N}-130^{\circ} 08^{\prime} \mathrm{E}\right)$, 11.VII.2010, Bezgodov \#396a (MHA). Khabarovsk Territory, Sovgavan District, Botchinsky Nature Reserve, slope of Shapka Hill to Mulpa River $\left(48^{\circ} 17 \mathrm{~N}-139^{\circ} 37 \mathrm{E}\right)$. Ignatov \& Ignatova \#13-1079 (MHA).

Ecology. In North Urals, Pohlia lutescens was collected in forest belt, at $\sim 300-460$ m a.s.l., in wet Calamagrostistall-herb conifer forests with Calamagrostis purpurea (Trin.) Trin. s. 1., Aconitum septentrionale Koelle, Filipendula ulmaria (L.) Maxim., Geranium sylvaticum L., Dryopteris expansa (C. Presl) Fraser-Jenkins \& A. Jermy, on bare soil under upturned roots of fallen trees, and on overburden dump with loose herb cover. In Amurskaya Province, it was also found in lowland, at $250 \mathrm{~m}$ a.s.l., at the edge of steep slope at river bank. In Khabarovsk Territory, the locality of the species was at $370 \mathrm{~m}$ a.s.1., in dark conifer forest on steep slope of a hill with cliffy outcrops, on bare soil. P. lutescens forms almost pure loose tufts (\#575, Perm Province), or grows as an admixture to other bryophytes inhabiting various kinds of bare soil: Pohlia andrewsii A. J. Shaw, P. proligera (Kindb.) Lindb. ex Broth., P. drummondii (Müll. Hal.) A. L. Andrews, P. wahlenbergii (F. Weber \& D. Mohr) A. L. Andrews, Ceratodon purpureus (Hedw.) Brid., Ditrichum cylindricum (Hedw.) Grout, D. pusillum (Hedw.) Hampe, Bryum amblyodon Müll. Hal., Atrichum flavisetum Mitt., Polytrichum piliferum Hedw., Campylium sommerfeltii (Myrin) J. Lange, Pogonatum dentatum (Brid.) Brid., P. urnigerum (Hedw.) P. Beauv., and Polytrichum juniperinum Hedw.

Distribution. Not long ago Pohlia lutescens was considered to be an endemic of Europe (Smith, 2004), extending from Italy to Scandinavia. In Great Britain, it is rather common at places in England, Wales, and Ireland and rare in Scotland (Smith, 1.c.). In Scandinavian countries, it was recorded only in lowland southern Sweden and Denmark, being absent in Norway and Finland (Weibull \& Hallingbäck, 2008). In East Europe, it is recorded from Poland (Ochyra et al., 2003), but is still unknown in Baltic countries and Ukraine (Ignatov, Afonina, Ignatova et al., 2006). Outside Europe, it was recently found in several provinces of China, including NE part of Inner Mongolia, close to the boundary with Russia (Zhang et al., 2007). These authors also cite the species for Japan; however, it is absent in the latest checklist of mosses of this country (Iwatsuki, 2004). 


\section{ACKNOWLEDGEMENTS}

We thank the staff of Vishersky, Norsky and Botchinsky State Nature Reserves for arrangement of our field work. The work was partly supported by RAS Program "World Life: Current State and Development".

\section{LITERATURE CITED}

IGNATOV, M.S., O.M. AFONINA \& E.A. IGNATOVA (eds.) 2006. Checklist of mosses of East Europe and North Asia. - Arctoa 15: 1-130.

IWATSUKI, Z. 2004. New catalog of the mosses of Japan. - J. Hattori Bot. Lab. 96: 1-182.
OCHYRA, R., J. ŻARNOWIEC \& H. BEDNAREK-OCHYRA. 2003. Census catalogue of Polish mosses. - Biodivers. Poland 3: 1-372.

SMITH, A.J.E. 2004. The moss flora of Britain and Ireland. 2 ed. - Cambridge, Cambridge University Press, $1012 \mathrm{pp}$.

WEIBULL, H. \& T. HALLINGBÄCK 2008. Bryaceae. - In: Hallingbäck, T., N. Lönnell \& H. Weibull(eds.). Nationalnyckeln Sveriges Fl. Fauna. Bladmossor/Bryophyta. Bladmossor: Kompaktmossor-kapmossor. Bryophyta: Anoectangium-Orthodontium. ArtDababanken, SLU, Uppsala, Sweden. 504 pp.

ZHANG, D.-C., LI X.-J. \& SI HE 2007. Bryaceae. - In: Moss Flora of China. Vol. 4. Science Press \& Missouri Botanical Garden, Beijing, New York \& St. Louis: 3-92. 